
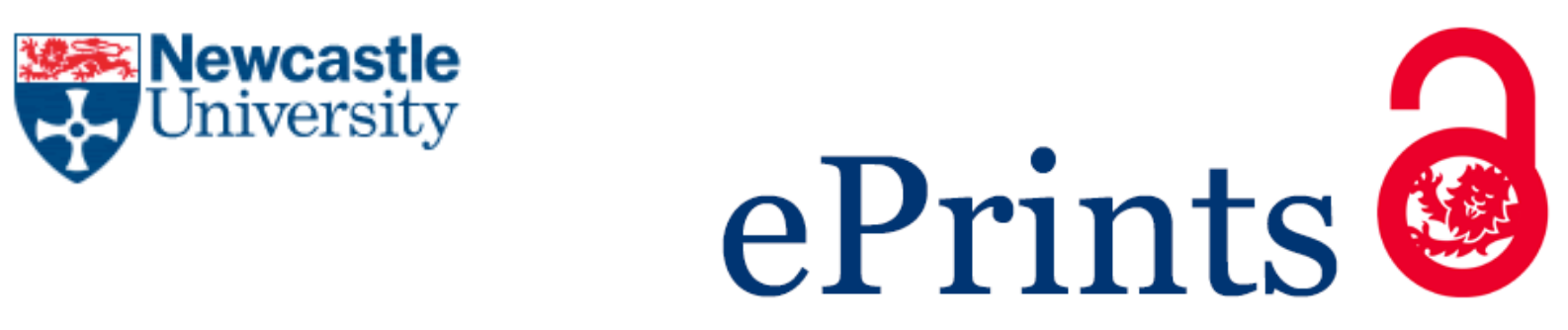

Kelsey D, Bennett L. Discipline and resistance on social media: Discourse, power and context in the Paul Chambers 'Twitter Joke Trial'. Discourse, Context and Media 2014, 3, 37-45.

\title{
Copyright:
}

(C) 2014. This manuscript version is made available under the CC-BY-NC-ND 4.0 license

DOI link to article:

http://dx.doi.org/10.1016/j.dcm.2013.12.001

Date deposited:

$22 / 02 / 2016$

Embargo release date:

02 January 2015

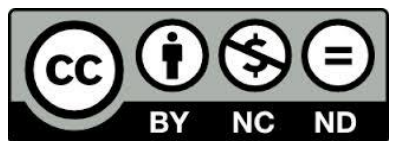

This work is licensed under a

Creative Commons Attribution-NonCommercial-NoDerivatives 4.0 International licence 


\section{Discipline and resistance on social media: Discourse, power and context in the Paul Chambers 'Twitter Joke Trial'}

\section{Introduction}

On $6^{\text {th }}$ January, 2010, Twitter user Paul Chambers posted the following message: "Crap! Robin Hood airport is closed. You've got a week and a bit to get your shit together otherwise I'm blowing the airport sky high!!". Although airport staff who saw the tweet did not view it as a threat, it was passed on to the authorities before anti-terror police later charged Chambers for "sending a public electronic message that was grossly offensive or of an indecent, obscene or menacing character contrary to the Communications Act 2003" (Bowcott, 2012). After two unsuccessful appeals Chambers received support from celebrities and other Twitter users who criticised the courts and authorities for their treatment of the case. He eventually had the conviction overturned in a successful High Court appeal.

It was argued, long before the arrival of social media, that computer-mediated communication is unable to replicate elements of face-to-face communicative nuances (Rheingold, 1992). Rheingold claimed that filtration factors of virtual communities prevented the exchange of facial expressions, readings of body language, or reception of vocal tones that are vital components in most face-to-face communication. Consequently, Rheingold argued, "Irony, sarcasm, compassion, and other subtle but all-important nuances that aren't conveyed in words alone are lost when all you can see of a person are words on a screen" (Rheingold, 1992:427). But Rheingold's claim was arguably simplistic and scholars since then have highlighted some of the communicative, text-based nuances that do reflect emotions and gestures beyond the written language of computer-mediated technology (Thurlow \& Mroczek 2010; Herring, 2001; Dresner and Herring, 2012; McNeill, 2005; Kendon, 1995). Nonetheless, as Dresner and Herring (2012) point out, facial expressions in face-to-face exchanges are not always deliberate or conscious yet 'emoticons', for example, are always used consciously and deliberately to serve a specific purpose. Amongst other points, this reflects the ongoing complexity of debates about the role of communicative tools and features in digital media. Such debates are relevant to the Chambers case but stretch beyond the scope of this article. Therefore, their significance should be noted for the context of our discussion.

As the Chambers case shows, other Twitter uses were able to read the tweet in the context that Chambers intended and used other techniques to express their support for him (reflecting communicative nuances like irony and sarcasm). Therefore, this paper argues that contextual and interpretive ambiguities on social media occur partly due to the absence of expressional nuances in computer-mediated communication. But there are further complexities concerning context, power and social relations that account for different readings of, and responses to, social media texts. By accounting for these relations we provide a critical perspective on the authoritative and institutional practices involved in the Chambers case. It is our approach to 
critical discourse studies (CDS) that enables us to investigate the oppositional dynamics that occurred in the Chambers case.

\section{Critical discourse studies and digital media}

Throughout this paper we often refer to two, similar acronyms: CDS (Critical Discourse Studies) and CDA (Critical Discourse Analysis). CDS is used to refer to a broad discipline of discourse research, whilst CDA is used to refer to particular models and approaches that have been designed to analyse discourse in certain ways. It is also important to clarify that whilst we develop an approach for analysing digital media we do not provide a linguistic analysis of any specific text. Rather than analysing the linguistic elements that CDA often addresses in great detail, this paper focuses on theoretical approaches to discourse, power and context (Fairclough, 1995; van Dijk, 1998, 2001; Marwick, 2012; KhosraviNik, 2014) and surveillance theory (Bauman and Lyon, 2013; Doyle, 2011; Jurgenson, 2013; Jensen, 2007; Deuze, 2012; Mathiesen, 1997) that we argue are relevant to social media. As Herring states, "the discursive negotiation and expression of social relations in cyberspace including asymmetrical relations, constitutes to be one of the most promising areas of future investigation." (2001:625). The theoretical underpinnings of critical discourse studies are not only relevant to digital media research, "but as a socially committed, problem-oriented, textually based study, CDA cannot shy away from substantially engaging with the new media communications as emerging sites of discursive struggles" (KhosraviNik, 2014: np). Although research on social media contexts is yet to become prolific in the field of CDS, some scholars have begun to consider the importance of digital media in this field (Wodak and Wright, 2006; Mautner, 2005; Unger, 2012). For example, Wodak and Wright (2006) examined the European Union's Futurum discussion forum to show "that multilingual interaction was fostered, and that the debate about language policies is politically and ideologically charged" (2006:251). Unger has considered the "implications of adopting a CDS framework in online contexts, particularly when faced with 'web 2.0' phenomena such as social networking, crowd-sourcing and participatory media" (2012). As Unger states, "CDS is advantageously placed, as a loose, adaptable theoretical approach rather than a rigid methodological framework, to investigate these new contexts, but it requires new tools to fully realise its potential" (ibid). By refining a traditional framework that is commonly adopted in CDS, and incorporating surveillance theory into this approach, we provide one example of how CDS can begin to realise such potential.

In this paper, we show that Fairclough's (1995) three layered model of CDA and previous approaches to context (Fairclough, 1989; van Dijk, 1998, 2001; Marwick, 2012; KhosraviNik, 2014) can be adopted to investigate the power dynamics of social media. Fairclough's approach to CDA attempted to "transcend the division between work inspired by social theory which tends not to analyse texts, and work which focuses upon the language of texts but tends not to engage with social theoretical issues" (2003:2-3). As Fairclough states, "discourse analysis is not merely the linguistic analysis of texts. I see discourse analysis as 'oscillating' between a focus on specific texts and a focus on what I call the 'order of discourse"" (ibid:3). Therefore, within Fairclough's framework we incorporate previous approaches to panoptic, synoptic and omnioptic/omnoptic surveillance (Bauman and Lyon, 
2013; Doyle, 2011; Jurgenson, 2013; Jensen, 2007; Deuze, 2012; Mathiesen, 1997). In doing so, we propose the concept of synoptic resistance as an example of power and social practice operating through social media. We hope that by understanding the theoretical propositions of this paper, CDS scholars can consider our approach when conducting future research on social media and developing innovative frameworks in CDS. The following section provides a brief summary of the Twitter Joke Trial, which we will refer to throughout our discussion.

\section{Paul Chambers and the 'Twitter Joke Trial' 1}

In January 2010 cold weather and heavy snow across the UK resulted in severe transport delays, including the cancelation of flights and closure of airports. Paul Chambers was supposed to fly from Robin Hood Airport a week after it had been closed due to weather conditions. As his solicitor, David Allen Green ${ }^{2}$ explained:

The facts of Paul Chambers v Director of Public Prosecutions are straightforward. Chambers was at home in the north of England when he heard news that his local airport was to be closed because of snow. He sent a "tweet" to his followers stating his exasperation. He was to fly to Northern Ireland to stay with a girl with whom he hoped to have a relationship. The tweet was not addressed to the airport and he had no reason to believe that the airport would see it: in this way the case is not analogous to the person jesting at an airport ticket barrier. In his tweet he said he wanted the airport to sort out the snow problem or he would blow it sky high. It was not intended to be serious, and it clearly was not serious, written in jokey language under his own name and with his own picture as an avatar. It may well have been unwise, and it may not have been particularly funny, but it was not a "bomb hoax" or any directed threat (Preiskel and Green, 2011).

A week after the tweet Chambers was arrested at work, his house was searched and electronic devices - including his computer hard drive - were confiscated. Under the Communications Act 2003, Chambers was found guilty for sending a 'menacing' message. He was initially fined $£ 350$ and by November 2010 alone, the court costs he was ordered to pay had reached $£ 2,600$ (Green, 2010). Chambers also lost his job as an accountant following the conviction. The reason this case had been pursued by the Crown Prosecution Service (CPS) was due to an amendment of the United Kingdom's Communications Act, which in 2003 had been changed in order to encompass electronic media beyond telephony:

The provision is section 127(1) of the United Kingdom's Communications Act 2003, which prohibits messages or other matter sent by means of "Public Electronic Communications Network" that are of a "grossly offensive or of an indecent, obscene or menacing character". ... Before the 2003 Act it was for telephony only, but there

\footnotetext{
${ }^{1}$ This section draws heavily on legal accounts and sources purely for the sake of accuracy and authority in our summary of the case.

${ }^{2}$ Green was not Chambers' original lawyer when he was charged and convicted but he represented him in his appeals.
} 
are almost no records of it ever being used in practice. However, with the 2003 Act, the scope of the offence widened to include messages and other material conveyed by a "Public Electronic Communications Network". This, in effect, meant the whole of the internet. It is not clear whether this extension was deliberately intended by the legislature; but it certainly is the natural consequence of the definitions used (Preiskel and Green, 2011).

Chambers appealed three times against his conviction before his successful High Court appeal saw the conviction overturned in 2012. In response to the first appeal the judge, Jacqueline Davies questioned Chambers' honesty after he claimed to be unaware of the potential impact the message might have. Referring to Chambers as an 'unreliable witness', Davies came to the following conclusion:

"Anyone in this country in the present climate of terrorist threats, especially at airports, could not be unaware of the possible consequences." She also described some of his earlier evidence as "self-serving" and cast doubt on his claims not to have kept up to date with current affairs through newspapers or TV. As for the tweet at the centre of the case, she called it "menacing in its content and obviously so. It could not be more clear. Any ordinary person reading this would see it in that way and be alarmed" (Wainwright, Guardian, 2012).

As these contrasting accounts of solicitor and judge demonstrate, context is central to this story: who was saying what, how were they saying it, and what purpose was it intended to serve? We are concerned with this particular case since it was not just significant to internet laws and future prosecutions that we address below; but it demonstrates the necessity for theoretical understandings of discourse, context, power and social practice in online communications.

Chambers' later lost another High Court appeal in 2012 before the conviction was final quashed. But his unsuccessful appeals had increased the profile of the case and he gained considerable support from celebrities, lawyers, political commentators and Twitter followers (including Graham Linehan, Charlie Brooker, Dara O'Brien and Nick Cohen). Stephen Fry and Al Murray also accompanied Chambers at the High Court for his successful appeal. Fry had already insisted he would cover the costs of Chambers' fines. Chambers gained further support on Twitter where his message was retweeted by more than 18,000 users, often using the hashtag '\#IAmSpartacus' in protest against the conviction and unsuccessful appeal. Notably, this is not only proof of the support that Chambers received on Twitter, but nobody quoting or retweeting his statement faced criminal charges either. When Chambers finally won his court battle it also emerged that there were conflicts of opinion amongst the CPS; a decision had been made to drop Chambers' case until a last minute intervention from the director of public prosecutions (DPP), Keir Starmer, who overruled the decision. Amongst heavy criticism for letting the case continue, Starmer was accused of wasting public money of the CPS and putting Chambers through further unnecessary stress. 
The 'Twitter Joke Trial' provided new problems and concerns for users of social media. Fortunately, as one of Chambers' legal representatives clarified after the case, this was a positive outcome for these users:

John Cooper QC, who represented Chambers, said: "It's an important decision for social networks. It means that in future not only does a message have to be of a truly menacing character but the person who sends it has to intend it to be menacing. "Now people can have a joke even if it's a bad joke ... this case should never have been prosecuted and it may be that the CPS will have questions to answer about this" (Bowcott, 2012).

But from Chambers' initial actions, through to his arrest, conviction, failed appeal, subsequent support and successful appeal, what can we learn from this case for future research on discourse and power? We argue that critical analysts can refine and apply current frameworks of discourse, social practice and power to understand processes of production, context, interpretation and consumption of social media texts. We will explore the theoretical elements that are applicable to the Chambers case and the details we have covered so far. Many of the approaches adopted below were not necessarily developed with the environments and practices of online or social media in mind. But our attention to the Paul Chambers case shows how these models still hold relevance when they are refined and applied to contemporary modes of communication.

\section{Discourse, context and social practice}

The judge's view of Chambers' tweet contrasts with those of the lawyers representing Chambers since they apply different contexts to his actions. We argue that the conflicting views of this case derived from two discursive mechanisms that are central to traditional approaches to CDA: context and power. Contextual interpretations (explaining the thoughts, intentions and meaning of a text producer) through computer-mediated communications (like social media) have further complicated processes of production and consumption in discursive exchanges. As KhosraviNik argues, new media developments have changed the "traditional one-way and linear dynamics of text production, distribution and consumption in mass communication" (2014, np). Yet our understanding of discourse, context, and social practice (that we refine and apply appropriately in light of these media and communicative developments) draws on Fairclough's model (1995) since it accounts for a synergy of terms text, discourse, production, interpretation, context and social practice - that are still suitable for exploring the concerns addressed in this paper.

\subsection{Discourse and context}

By considering discourse from a functionalist perspective - that considers texts in context scholars of CDA have addressed the ideological agency of discourse and social practice whilst challenging dominant or exploitative power relations (Fairclough, 1995; Richardson, 2007; Wodak, 2001, 2008; Wodak et al., 1999; van Dijk, 1998). A functionalist approach 
considers how language is used and what purpose it is designed to serve. Discourse can both restrict and mobilise certain discussions of a topic: "Just as discourse 'rules in' certain ways of talking about a topic . . . it 'rules out', limits and restricts other ways of talking . . . in relation to the topic or constructing knowledge about it" (Foucault in Hall, 2001: 72-73). Discourse is therefore "a culturally and socially organized way of speaking" (Mayr, 2008: 7). Fairclough (1995) argues that language use (meanings) are defined by social conventions that operate in the production and consumption of texts - in other words, language is not separate from society but it is part of society itself. Whilst we are concerned with oppositional readings and proceedings in the Chambers 'Twitter Joke Trial' - rather than providing a linguistic analysis of the tweet or any other related texts - we will explain the discoursetheoretical aspects that we argue are relevant to this case below.

But before proceeding, let us consider some details of David Allen Green's own analysis of the message that Chambers sent. Firstly he points to the context that he is aware of due to the background knowledge he has of the individual concerned:

Paul's original tweet was the hyperbolic statement of exasperation of someone discovering that he may not get to see a girl he fancied. It was not intended to be menacing, and indeed it was not menacing (Green, 2010).

Then he provides a more nuanced account of the language that Chambers used and its grammatical structure in order to provide context to a reading of the message:

Look at the tweet carefully: "Crap! Robin Hood airport is closed. You've got a week and a bit to get your shit together otherwise I'm blowing the airport sky high!". From the very first word -- an expletive followed by an exclamation mark -- it is clear to any reader that it was not serious. The proposition which follows -- an emphatic and sweary call for an airport to be opened rather than for it to be closed -- is simply nonsensical as a threat on its own terms. This is not how a terrorist, a hoaxer, or anyone with any menacing intent, would actually make their wrongful statements (ibid).

As we acknowledged in our introduction, the clarity of tones and nuances in face-to-face communications is compromised as words on a screen through computer-mediated technologies. But as Herring points out, "computer mediated discourse may be, but is not inevitably shaped by technological features of computer mediated communication systems" (2004: 343). So it is not that the authorities were completely blind in their reading of the text. The airport staff that passed the tweet on were not initially concerned by it, which suggests a contextual nuance in their reading to begin with. But the authorities' position of power and perception of responsibility to act influenced the context that they applied in their reading of the tweet.

Since readers interpret texts (and the intentions of the producer) in different ways, according to the resources they draw upon (van Dijk, 2001), this is where our concerns lie: in that texts (tweets) are part of discursive processes in which institutional power can be exerted through 
interpretations that overlook, or at least fail to understand, the intentions of the text producer. Marwick's work considers the concept of 'context collapse' occurring on social media:

Social media involves a collapse of social contexts and social roles, complicating boundary work but facilitating social surveillance. Individuals strategically reveal, disclose and conceal personal information to create connections with others and tend social boundaries. These processes are normal parts of day-to-day life in communities that are highly connected through social media (2012: 378).

The Chambers case demonstrates the problematic power relations that can occur in readings of online texts (rather than face-to-face conversations or expressions), which are 'misinterpreted' due to the social contexts upon which they are read. As Nick Cohen argued during the Chambers case:

People joke like this all the time. When they say in a bar: "I'll strangle my boyfriend if he hasn't done the washing up" or post on Facebook: "I'll murder my boss if he makes me work late", it does not mean that the bodies of boyfriends and bosses will soon be filling morgues. You know the difference between making a joke and announcing a murder, I'm sure. Apparently the forces of law and order do not (2010).

So context is crucial to production and interpretation. Considering context means that we try to understand how and why texts are produced.

The ways in which contexts are realised or constructed have received considerable attention across various disciplines of social, psychological, and discursive fields of research (Androutsopoulos, 2008; Auer \& Di Luzio, 1992; Duranti \& Goodwin, 1992; Gumperz, 1982; KhosraviNik, 2014; van Dijk, 2001; Wodak at al., 1999). We do not wish to propose one fixed theory of context; we consider various elements of different approaches considered below as valuable input towards understanding context for the purpose of this paper. ${ }^{3}$ Ethnographic theories of context (Auer \& Di Luzio, 1992; Duranti \& Goodwin, 1992; Gumperz, 1982) have considered "the relevant structures of whole communicative events, and not just on the structures of text or talk as part of such events, and such events also include a setting, participants, goals, etc.” (van Dijk, 2001:19). Androutsopoulos' (2008) ethnographic approach considers a combination of online environmental factors and other communicative practices that participants potentially are involved in. KhosraviNik explains this approach in further detail:

Emphasis is also on the role of context, as in questions about users' motivations for the use of a particular resource online, the meanings they attach to those resources, and relationship between participants. In foregrounding online ethnography, there is an emphasis on systematic observation within 'web environments' starting from the

\footnotetext{
${ }^{3}$ We also recognise the relevance of previous work on "interpretive communities" (Blatt, 2001; Fiske and Hartley, 1978; Fish, 1989; Hall, 1978). Whilst a detailed discussion of interpretive communities is beyond the scope or necessity of this paper it is important to recognise that interpretive community theory accounts for the different ways in which texts are read, consumed and understood according to the conceptual maps (and cultural knowledge) of audience members.
} 
core to the periphery of the field under investigation, identifying core participants, and reading member's self-descriptions $(2014, \mathrm{np})$.

This applies to the Chambers case since we are concerned with how the contextual interpretations of his tweet were formed by an interplay of structural and environmental considerations that include the goals and interests of different participants; whether they represent the interests of an individual (Chambers) the broader concerns of society (celebrities and protesters protecting freedom of speech) or the institutional interests and powers (national security, police, and the CPS).

As van Dijk argues in his cognitive approach to context, "whatever language users attend to in discourse is largely dependent on their model of the communicative situation. It is this model that keeps track of what the language users finds interesting or important, or otherwise relevant for their or his current aims" (2001:19). van Dijk describes context models as the cognitive constructions that we have of other participants in social situations. He explains that these models might be biased since they contain personal opinions and/or other opinions informed by affiliation with certain social groups that have particular concerns, goals or interests:

Indeed, a feminist and male chauvinist in conversation are likely to have pretty different context models, as do a liberal and a conservative, a professor and a student, and a doctor and a patient talking together. Indeed biased or incomplete context models are the source of profound communicative and interactional conflicts (ibid: 14).

However, it is important to note that "context models are not static mental representations, but dynamic structures" (ibid: 8). These are constantly constructed and reconstructed by different participants in discursive events or exchanges, "and they change with each change in (the interpretation) of the situation, if only because of the ongoing changes of discourse itself (one of the components of context)" (ibid: 8). As we saw in the Chambers case, "the discourse will dynamically change the knowledge the participants have about the knowledge of the other" (ibid:8). Furthermore, there are certain forms of knowledge that participants might carry but chose to suppress or neglect due to their institutional responsibilities. A judge might, for example, identify or understand the linguistic and grammatical details that Green (solicitor) highlighted above. But their institutional practice, professional conscience, interpretation and perception (or feeling of 'duty') might influence them otherwise. This brings us to the concept of discourse as social practice.

\subsection{Discourse as social practice}

Moving our discussion on to discourse as social practice, let us consider Fairclough's (1995) model of discourse in three layers: textual analysis, discursive practice, and social practice in the multi-layered production and consumption of texts. With a multidimensional approach in mind, this also accounts for macro and micro levels of discourse (van Dijk, 1998; Wodak, 2008). van Dijk defines these discursive dimensions: "Language use, discourse, verbal interaction, and communication belong to the micro level of the social order. Power, 
dominance, and inequality between social groups are typically terms that belong to a macro level of analysis" (1998:354). Discursive practices account for the textual and cognitive functions that "authors of texts draw on already existing discourses and genres to create a text and ... how receivers of texts also apply available discourses and genres in the consumption and interpretation of . . . texts" (Phillips \& Jorgensen, 2002: 69). Social practice then explains what a text reflects about society and the subsequent implications it can have on society - a common concern in CDA (Fairclough, 1995; Mayr, 2008; Richardson, 2007; van Dijk, 1998; Wodak, 2001, 2008). These are the levels at which we are concerned with discourse as social practice. For example, Green's analysis of Chambers' language, and the linguistic structure of his tweet, provides a textual (micro) analysis (Fairclough, 1995; van Dijk, 1998; Wodak, 2001, 2008) of the text. Subsequently, we can then consider the way the text was produced (by Chambers) and how different receivers of the message (Twitter users, lawyers, police, CPS) interpreted it (Phillips \& Jorgensen, 2002). Then we consider the implications of his message and subsequent conviction through the social practice (Fairclough, 1989) concerned. As we demonstrate in the following section, there are theoretical frameworks of power that can be applied to the social practice of this case and, more broadly, the phenomena of social media.

So Fairclough's approach to discourse as social practice reflects our concerns in this paper. He points out that not only is language a social process but it is a "socially conditioned process, conditioned that is by other (non-linguistic) parts of society" (ibid: 22). For Fairclough, the use of language in social contexts "is not merely a reflection or expression of social processes and practices, it is a part of those processes and practices" (ibid: 23). As he points out, meanings of words are often debated in politics: "People sometimes explicitly argue about the meanings of words like democracy, nationalisation, imperialism, socialism, liberation or terrorism" (ibid: 23). Contrary to the view that such debates are mere openings to, or extensions of, the central practices and 'real' processes of politics, Fairclough argues that these words and debates are politics. Language is political; it is part of social processes. Like Fairclough we "use the term discourse to refer to the whole process of social interaction of which a text is just a part" (ibid: 24). In the case of Chambers, referring to his tweet as a text means we consider it as part of a discursive process that is concerned with its production and consumption (or interpretation). Fairclough accounts for this as follows:

Discourse, then, involves social conditions, which can be specified as social conditions of production, and social conditions of interpretation. These social conditions, moreover, relate to three different 'levels' of social organization: the level of the social situation, or the immediate social environment in which the discourse occurs; the level of the social institution which constitutes a wider matrix for the discourse; and the level of society as a whole. What I am suggesting, in summary, is that these social conditions shape the [members' resources] people bring to production and interpretation, which in turn shape the way in which texts are produced and interpreted (ibid: 25)

However, in understanding discourse as social practice we consider not just production and interpretation, but also the "relationship between texts, processes, and their social conditions, 
both the immediate conditions of the situational context and the more remote conditions of institutional and social structures" (ibid:26). Meaning we scrutinise the power relations concerned through the relationship between text, interactions, and contexts as explained so far. Subsequently, language becomes regulated by forms of power through social and institutional practice. Whilst the courts provided their own response and context to the Chambers case, other forms of social power operated in opposition to and resistance against the prosecution of Chambers. It is here that we propose a refined system of panoptic and synoptic interplays of power operating through social media.

\section{Theoretical frameworks of panoptic and synoptic power}

Our position on power relations and social media draws heavily on the work of three scholars (Doyle, 2011; Foucault, 1977; Mathiesen, 1997) who provide different, albeit compatible, approaches to surveillance theory as models of social power and control. We do not intend to dismiss or embrace one set model of surveillance theory. But we do refine and reapply those aspects from previous theoretical frameworks that contribute towards the most applicable understanding of power through social media. Doyle's work is particularly important since it refined the approaches of Foucault (1977) and Mathiesen (1997) with more nuanced considerations of new media technologies and the internet. We then take Doyle's approach further by applying it more specifically to social media and in our conclusion we consider the implications of this for future research in the field.

In Discipline and Punish (1977), Foucault used Jeremy Bentham's panoptic prison - a central tower used by prison guards to monitor the movements of prisoners - as a metaphor to support his argument that the constant, potential gaze (surveillance) of the state in modern society disciplined people through self-regulation. In the case of the panoptic prison, when inmates are "never sure when they are being watched by someone in the central tower - or even if there is anyone in the tower at all - prisoners come by degrees to watch themselves..." (Ransom 1997: 47). Applying the analogy of Bentham's panoptic prison to modern society, Foucault argued that "our society is not one of spectacle, but of surveillance", where the few observe the many (1977: 217). He argued that the state's surveillance of modern society regulated and controlled the behaviour of individuals due to their awareness of the possibility (rather than certainty) than they were being watched. As Crawford explained, "the panopticon gaze may not reach into every facet of everyday life, but the key to panoptic discipline is that this is normalized and carried with the individual outside the scope of the gaze" (2004: 109).

Since Foucault's work other scholars have proposed more contemporary understandings of panoptic theory (Bauman, 1988; Fiske, 1993; Mathiesen, 1997). Whilst the panopticon model is still relevant, Mathiesen's (1997) critique of Foucault's work refined the application, disciplinary impact and role of panoptic surveillance in contemporary society. Without overlooking the relevance of panopticism, Mathiesen proposed the theory of synopticism: rather than a solely panoptic process of the few watching the many, the arrival of mass media and contemporary technologies meant that the many could watch the few. As he stated: 
the control and discipline of the 'soul', that is the creation of human beings who control themselves through self-control and who thus fit neatly into a so-called democratic capitalist society, is a task which is actually fulfilled by modern synopticon, whereas Foucault saw it as a function of panopticon (Mathiesen 1997: 215).

Mathiesen argue that this proliferation of synoptic control and power has resulted in publics becoming what he termed as 'the viewer society'. However, he strongly emphasised that rather than one theory replacing the other, "panopticism and synopticism have developed in intimate interaction, even fusion with each other" (1997: 223). Subsequently, he suggests, with the further development of technology, we can "clearly see tendencies for panopticism and synopticism to merge into one" (1997: 223). Whilst there is a clear case to support Mathiesen's point, he also dismissed any notion that the synopticon was a liberating form of power or resistance. He argued that it was still based on a concept of top-down power in which subjects of 'the viewer society' were simply distracted from the realities of their daily lives, and expansions of media consumption were used to legitimise the operations of a surveillance society (Doyle, 2011). As Jurgenson (2013) points out, Bauman also took this position in his description of the synopticon as "surveillance without surviallors', meaning that the many, by virtue of not being a powerful few, simply cannot be considered surviallors".

Mathiesen argued (accurately to some extent) that the basic conditions of the internet were "being set from above ... from the level of capital rather than from the level of participants, though they may still contain an illusion of two parties on an equal footing" (1997:225). Quite rightly, he pointed out that access to the internet and new media technologies in general was limited to certain social demographics. As we have seen, this is a growing concern in contemporary society (Livingstone, Bober \& Helsper, 2005; Livingstone \& Helsper, 2007, Wakefield, 2010) and we do not overlook this point. Furthermore, it is also the case that the internet provides "profound new opportunities for surveillance, including techniques in which millions participate through their own self-disclosure facilitated and encouraged by such massively popular websites as Facebook and Twitter. The internet dramatically enhances the massive project of consumer profiling" (Doyle, 2011:294).

As Doyle (2011) points out, since Mathiesen's revision of Foucault's panopticon most scholars (Bauman, 1998; Boyne, 2000; Elmer, 2003; Haggerty, 2006) have used synoptic theory to critique and highlight the limitations of Foucault's panopticon. Subsequently, "the synopticon notion has been taken up largely uncritically" (ibid: 287). Whilst acknowledging the caution that Mathiesen applies here, we maintain that power operates through more complex and potentially liberating relations (at least on social media). In a critically reflective response to previous synoptic theory, Heir argues that:

... a degree of caution must be exercised concerning the extent to which the synoptic should be embraced as a totalizing, deterministic space ... sensitivity to the complex relationship existing between the media and society, politics and social control is 
required ... media narratives embedded in complex discursive formations operate in fluid and, often, contradictory ways (cited in Doyle, 2011: 287).

Subsequently, Doyle maintained that Mathiesen's "notion of the synopticon is best relied on simply to raise the question of how surveillance and the mass media interact and are intertwined, rather than as a way of thinking about the role of the media in social control in general" (2011: 284). He challenged Mathiesen's dismissal of the internet as a potentially liberating tool by reviewing the synopticon in application to Web 2.0; proposing that the increasingly fragmented audiences of the Internet allow for more diverse and active resistance through the 'crucial countercurrents' that have occurred on a global scale (2011:295). In Castells' (2007) model of the Network Society he argues that the interactive nature of horizontal networks in new media technologies have enabled new forms of communication and mass self-communication to develop through the internet and wireless networks. Subsequently, Castells argues that: "Under these conditions, insurgent politics and social movements are able to intervene more decisively in the new communication space" (ibid:238). So whilst realising that the internet faces its own limitations, problems and challenges there are optimistic aspects to recognise in order to avoid an overtly pessimistic or deterministic view of top-down power. We now refine the approaches considered so far in order to explain how they apply following the events and outcome of the 'Twitter Joke Trial'.

\section{Interplays of power and synoptic resistance}

There are strong cases to suggest the internet has provided opportunities for resistance and oppositional power. In light of specific debates that have developed from panoptic and synoptic models, let us consider some events from the Chambers case. We argue that the 'Twitter Joke Trial' demonstrates panoptic (Foucault, 1977) and synoptic (Mathiesen, 1997) interplays of power through social media. But we refine the synergy of these models by demonstrating that resistance, opposition and 'countercurrents' of power are enabled through social media. For example, like the panopticon, the few watched the many, and tried to regulate their behaviour through the prosecution of Chambers. Hence, for many users, the Chambers case could have solidified and reinforced "a sense of self that is always subject to viewing by authority - and which therefore must forever engage in the measuring, grading, and censoring of behaviour" (McGrath, 2004: 7). If Chambers had lost his appeal then the implications for freedom of expression online could have been catastrophic (despite him winning his case, it is impossible to measure the impact this has had on the anxieties and future caution of users online). However, like the synopticon, the many also watched the few. But this 'watching' was more than a passive observance: through the protest tweets, Spartacus hashtag, celebrity support and subsequent representation in court, we argue that a synoptic resistance contributed to this interplay of panoptic and synoptic power. When the few were watched by the many, the many were condemned and (eventually) defeated. We have not suggested that the public directly pressurised or influenced the CPS (although this possibly happened, it is impossible to prove). But they did demonstrate solidarity and exposed the weaknesses of the CPS' position by mocking the law and retweeting Chambers' 
message, free of any criminal charges or prosecution. In proposing synoptic resistance we support the optimistic outlook of Doyle in recognising the potentially liberating power of the internet in certain cases.

Doyle (2011) and Elmer (2003) argued that whilst Mathiesen proposed the panopticon and synopticon reciprocated and mutually reinforced each other, he failed to develop any detailed example of how this worked. But given the case we have used to apply our theoretical framework, we believe we have overcome this potential limitation by showing how the synergy works in practice and how this understanding can be supported through the theoretical underpinnings of other approaches to CDA that we considered earlier. Although, as Doyle points out, audiences are fragmenting (2011: 293), the Chambers case was an example of the countercurrents that subsequently occur; resistant synoptic agency can bind together fragmented groups of users across a vast, global network. This discursive process featured an interplay of authoritative panoptic power and synoptic resistance that mobilised agency among users and provided groups with a sense of shared intentions, goals, and interests (power and context). Collective context was applied through the synoptic resistance of Twitter users.

To take these points a stage further, we suggest that social media should be also considered for its dynamic of the many watching the many. It is this model that provides the potential for certain actions, events and agency to occur through a synergy of panoptic and synoptic operations. In Liquid Surveillance (2013) Bauman and Lyon have noted the usefulness of panoptic metaphors but have also moved towards more complex understandings of postpanoptic and post-synoptic concepts of modern surveillance. Jensen (2007) has also referred to the omnopticon in which "people live in a state of constant mutual surveillance" (see Deuze, 2012:129). Further to this, as Jurgenson has argued, "An additional form of postpanoptic, and post-synoptic, surveillance is what George Ritzer and I have called 'omnioptic', that is, how the many watching the many is not only an increasingly powerful form of surveillance, but also the most liquid" (2013). Jurgenson previously called for a "better theory of how the surveillant gaze is both enacted by and upon the many (without forgetting the powerful role the few have in watching and being watched)" (ibid). Our approach has accounted for this whilst also revising the "top-down bias in much surveillance theorizing" and integrating more "lateral, social observation, not as separate from, but in conversation with, watching of and from the top" (ibid). Our approach provides a refined understanding of modern surveillance that is consistent with the liquid concept proposed by Bauman and Lyon (2013).

To remain cautious of such complex negotiations of power it should be noted: when the many watch the many, some of them might still inform, assist and serve the interests of the "former-few" or those with institutional power. This is not always a negative prospect either. But we stress that it is not our intention to propose a utopian devolvement of power that overrides all traditional, top-down practice. As Deuze points out, Jensen's omnopticon is "considered by some a social system that democratizes the panopticon, and can thus neutralise centralized, top-down hierarchical forms of authority" (2012:129). As we have shown, this might be the case in some instances but we do not suggest that those instances 
abolish macro structures of top-down power; they simply complicate and negotiate power relations within a broader social structure and dominant order. Rather like Gramsci's (1971) model, hegemonic power is never fixed or static since it is open to constant negotiation, resistance and change. Modern media technologies and society feature these synopticpanoptic interplays of power through battles of control and resistance. The implications of the latter might be positive or negative according to the interests (contexts) of certain groups and institutions concerned. In development of Heir's earlier point, panoptic and synoptic agency can still exert power but the practices that inform and support their authority have become more complex.

\section{Conclusion}

This paper has demonstrated the importance of studying discourse, context and power on social media. By considering the practical processes of online communication we have explored some of the issues that discourse participants experience online and the implications of their actions. Subsequently, we have highlighted the growing importance of understanding 'Individual Communicative Nuance' (ICN) in the production and interpretation of online texts. But ICN is not the only problematic practice of online communications since there are other social and environmental factors that impact upon the production, consumption and interpretation of social media texts. By accounting for the environmental and interpretative concerns of context models (Androutsopoulos, 2008; KhosraviNik, 2014; Herring, 2001; Marwick, 2012; van Dijk, 2001) we have demonstrated the growing importance of understanding context in critical analyses of social media. As KhosraviNik explains, the progressions in media communication technologies have mobilised "new interpretations of relations between text producers and consumers, as well as new (potential) arenas for public sphere debates" (2014: np). By adopting previous understandings of discourse as social practice (Fairclough, 1989) we have reviewed, refined and applied approaches to power (Bauman and Lyon, 2013; Doyle, 2011; Foucault, 1977; Jurgenson, 2013; Mathiesen, 1997) that are applicable to the social relations and complex power dynamics of social media. These relations and dimensions of power are unfixed and constantly shifting according to the contextual environments upon which they are produced and consumed. Hence, CDA can help us to understand, unravel and explore current operations and dimensions of discourse and power in online environments. As Fairclough (1989) argued, language is defined by social conventions and regulated by forms of power through social and institutional practice. In this sense, we may see a change in the social conventions of language used online; altering and complicating in accordance with users constructing and posting messages within panoptic, synoptic and omnioptic interplays of power relations.

We have shown that CDS can provide the tools and frameworks necessary for scrutinising power relations in new media technologies. CDS can fulfil the potential that Unger (2012) called for earlier. From this theoretical approach we have proposed the concept of synoptic resistance, which enables oppositional power against panoptic state surveillance. But we do not deny that broader social structures still contain top-down power; this clearly still exists 
and, as we have seen, institutions can take advantage of online media environments to exert power (Bauman and Lyon, 2013; Doyle, 2011; KhosraviNik, 2014; Mathiesen, 1997). But the complex interplay of social relations in certain media environments exercise less monolithic forms of power that produce oppositions, resistance and negotiated power (Doyle, 2011; Jurgenson, 2013). The few still watch the many, but the many watch the few, and the many watch the many. But the many do not necessarily watch passively; they can be active, collectively liberating, and they do resist authority. Alternatively, as we saw during the England riots of 2011, the many can assist the few and provide extended surveillance on their behalf (Baker, 2011; Harrison, 2011). But as we also saw at the time, mobile communications can be used to organise civil disobedience (Douglas, 2011). Whilst the actions of users online can be collectively liberating, they can also be collectively divisive or menacing. ${ }^{4}$

These complexities and emerging debates provide further nuances to consider in collaboration with current work that stretches beyond this paper. The issues we have covered are clearly significant in debates about the public sphere (Habermas, 1992; 1974) and how it functions through the internet and digital media (Papacharissi, 2002; 2010; Wodak and Wright, 2006). As we briefly discussed, Castells' concept of the "network society" (2010; $2007 ; 2012)$ is also relevant to the interplays of power that we have investigated and the ways in which people connect with each other through digital media. As Castells argues, there are cultural, social, political, economic and institutional factors, which influence the ways in which a network society functions, rather than purely technological processes. Digital activism (Hands, 2011; Cammaerts, Mattoni, and McCurdy, 2013; Castells, 2012; Gerbaudo, 2012, Mercea, 2013) is also a growing field of interest that is relevant to our theoretical approach and concept of synoptic resistance. Work across these fields should realise the interdisciplinary relevance of studies that are providing increasingly complex perspectives on digital media discourse and technologies.

Synoptic-panoptic interplays of power and 'omnioptic' or 'omnoptic' activity (Jurgenson, 2013; Deuze, 2012; Jensen, 2007) will continue to impact upon the social and discursive practices of digital media. Take the forthcoming introduction of the Twitter 'report abuse' button for instance; this process will allow users to report tweets that are deemed abusive or menacing (Cookson, 2013). Subsequently, the contextual and interpretive ambiguities of social media and social surveillance will become increasingly relevant and may further impact on how users compose tweets. For instance, more caution may be exercised by individuals during composition, who are wary of the surveillance operations that occur through social media: the potential gaze (surveillance) of other users (or institutions) may increase caution and self-regulation. In addition, individuals may revert to developing more tools like hashtags and emoticons in order to enhance the ICN of their message (although this approach may also have its limitations for the reasons we discussed).

\footnotetext{
${ }^{4}$ For example, the recent case when rape threats were sent to feminist campaigner Caroline Criado-Perez (Taylor, 2013). Or the issues arising from the Lord McApline story when he was wrongly accused of paedophilia (Strudwick, 2013).
} 
Carrying this forward for future research in CDS, it should be noted that the power relations of any discursive event (or process) have the potential to shift and evolve due to the contextual environments in which they operate. In the Chambers case, users saw the actions and retweets of other users and mobilised resistance against the state; siding with the individual who previously lacked power. But this might not always be the case. If misinformation, hyperbole and presupposition (amongst other discursive traits commonly considered in CDS) mobilise online agency that sees vulnerable groups exploited and opposed by popular opinion, then critical analysts will need to monitor these power relations closely.

\section{Bibliography}

Androutsopoulos, J. (2008) 'Potentials and limitations of discourse-centred online ethnography'.Language@Internet, vol., 5 article 9.

http://www.languageatinternet.org/articles/2008/1610 [Accessed 30 July 2013].

Auer, P., \& Di Luzio, A. (eds.) (1992). The contextualisation of language. Amsterdam: Benjamins.

Baker, S.A. (2011) 'Policing the Riots: New Social Media as Recruitment, Resistance and Surveillance' in Briggs, D. (ed.) The English Riots of 2011: A Summer of Discontent. Hampshie: Waterside Press.

Bauman, Z. (1988) Globalization: The Human Consequences. Oxford: Blackwell.

Bauman, Z. and Lyon, D. (2013) Liquid Surveillance: A Conversation. Cambridge: Polity.

Blatt, W. (2001) 'Interpretive Communities: The Missing Element in Statutory Interpretation'. Northwestern University Law Review, 95:2, 629-690

Bowcott, O. (2012) Twitter joke trial: Paul Chambers wins high court appeal against conviction. The Guardian. 27 July 2012. http://www.guardian.co.uk/law/2012/jul/27/twitterjoke-trial-high-court [Accessed 30 July 2013].

Boyne, R. (2000) 'Post-Panopticism', Economy and Society, 29(2), 285-307.

Cammaerts, B., Mattoni, A., and McCurdy, P. (eds.) (2013) Mediation and Protest Movements. Bristol: Intellect.

Castells, M. (2007) 'Communication, Power and Counter-Power in the Network Society', International Journal of Communication, 1, 238-66.

Castells, M. (2010) The Rise of the Network Society: Information Age: Economy, Society, and Culture v. 1 West-Sussex: Wiley-Blackwell.

Castells, M. (2012) Networks of Outrage and Hope: Social Movements in the Internet Age. Cambridge: Polity 
Cohen, N. (2010) Twitter and terrifying tale of modern Britain. The Guardian. 19 September 2010. http://www.guardian.co.uk/commentisfree/2010/sep/19/nick-cohen-terrorism-twitter [Accessed 30 July 2013].

Cookson, R. (2013) Twitter will simplify reporting of abuse. Financial Times. 28 July 2013. http://www.ft.com/cms/s/0/88474ff0-f76e-11e2-a618-00144feabdc0.html\#axzz2aQxvt7Ga [Accessed 30 July 2013].

Crawford, G. (2004) Consuming Sport: Fans, Sport and Culture. London: Routledge.

Deuze, M. (2012) Media Life. Cambridge: Polity

Douglas, T. (2011) 'Social media's role in the riots'. BBC. 9 August 2011.

http://www.bbc.co.uk/news/entertainment-arts-14457809 [Accessed 30 July 2013].

Doyle, A. (2011) 'Revisiting the synopticon: Reconsidering Mathiesen's "The Viewer Society" in the age of Web 2.0', Theoretical Criminology, 15 (3), 283-99.

Dresner, E. and Herring, S. (2012) 'Emoticons and illocutionary force' in Reisenfeld, D. and Scarafile, G. (Eds) Philosophical dialogue: Writings in honor of Marcelo Dascal. (pp.59-70) London: College Publication.

Duranti, A. \& Goodwin, C. (eds.). (1992) Rethinking context: Language as an interactive phenomenon. Cambridge: Cambridge University Press.

Elmer, Greg (2003) 'A Diagram of Panoptic Surveillance'. New Media and Society, 5(2), 231-47.

Fairclough, N. (1989) Language and Power. Longman: Essex

Fairclough, N. (1995) Critical Discourse Analysis: The Critical Study of Language. Essex: Longman

Fish, S. (1989) Doing What Comes Naturally: Change Rhetoric and the Practice of Theory in Literary and Legal Studies. Durham NC: Duke University Press

Fiske, J. (1993) Power Plays, Power Works. London: Verso.

Fiske, J. and Hartley, J. (1978) Reading Television. London: Methuen \& Co. Ltd.

Foucault, M. (1977) Discipline and Punish: the birth of the prison. New York: Vintage Books (1995 edition).

Gerbaudo, P. (2012) Tweets and the Streets: Social Media and Contemporary Activism. London: Pluto

Gramsci, A. (1971) Selections from the Prison notebooks. New York: International Publishers 
Green, D. A. (2010) The Twitter Joke Trial Carries On. New Statesman. 23 November 2010. http://www.newstatesman.com/blogs/the-staggers/2010/11/paul-menacing-criminal-court [Accessed 30 July 2013].

Gumperz, J. (1982) Discourse strategies. Cambridge: Cambridge University Press.

Habermas, J. (1974) The Public Sphere: an encyclopedia article (1964). New German Critique 3, 49-55.

Habermas, J. (1992) The Structural Transformation of the Public Sphere: an Inquiry into a Category of Bourgeois Society. Cambridge, MA: MIT Press.

Haggerty, Kevin D. and Richard V. Ericson (2000) 'The Surveillant Assemblage', British Journal of Sociology, 51(4), 605-22.

Hall, S. et al. (1978) Policing the Crisis: Mugging, the State, and Law and Order. London: Macmillan

Hall, S. (2001) 'Foucault: Power, Knowledge and Discourse' in Wetherell, M. and Taylor, S. (eds.) Discourse Practice and Theory: A reader, London: Sage.

Hands, J. (2011) @ is for Activism: Dissent, Resistance and Rebellion in a Digital Culture. London: Pluto

Harrison, T. (2011) DIY Justice: Catch a Looter. The Huffington Post. 8 September 2011. http://www.huffingtonpost.co.uk/tara-harrison/diy-justice-catch-a-loote_b_922088.html [Accessed 30 July 2013].

Herring, S.C. (2001). 'Computer-mediated discourse' in D. Schiffrin, D. Tannen, and H. Hamilton (eds.), The Handbook of Discourse Analysis (pp. 612-634). Oxford: Blackwell Publishers.

Herring, S. C. (2004). 'Computer-mediated discourse analysis: An approach to researching online behavior' in S. A. Barab, R. Kling, \& J. H. Gray (eds.), Designing for Virtual Communities in the Service of Learning (pp. 338-376). New York: Cambridge University Press.

Jensen, J. L. (2007). 'The internet omnopticon: surveillance or counter-insurgency' In Bang, H., \& Esmark, A. (Eds.), New Publics with/out Democracy. (pp. 351-380). Frederiksberg: Samfundslitteratur.

Jurgenson, N. (2013) "Liquid Surveillance \& Social Media: Three Provocations. Cyborgology. http://thesocietypages.org/cyborgology/2013/02/25/liquid-surveillance-socialmedia-three-provocations/ [Accessed 30 July 2013].

Kendon, A. (1995) Gestures as illocutionary and discourse structure markers in Southern Italian conversation. Journal of Pragmatics, 23: 247-279.

KhosraviNik, M. (2014, forthcoming) 'Critical Discourse Analysis, Power and New media (digital) Discourse: Issues and Debates' in Kopytowska, M. and Kalyango, Y. (eds.) (2014) 
Why Discourse Matters: Negotiating Identity in the Mediatized World. New York: Peter Lang.

Livingstone, S., Bober, M. and Helsper, E. (2005) Inequalities and the digital divide in children and young people's internet use: findings from the UK Children Go Online project. 5. London School of Economics and Political Science, London, UK. http://eprints.lse.ac.uk/398/ [Accessed 30 July 2013].

Livingstone, S. and Helsper, E. (2007) Gradations in digital inclusion: children, young people and the digital divide. New media \& Society, 9 (4), 671-696.

Marwick, A. (2012). The Public Domain: Social Surveillance in Everyday Life. Surveillance and Society, 9(4). http://library.queensu.ca/ojs/index.php/surveillance-andsociety/article/view/pub_dom [Accessed 30 July 2013].

Mathiesen, T. (1997) The viewer society: Michel Foucault's panopticon revisited. Theoretical Criminology, 1 (2), 215-234.

Mautner, G. (2005) Time to get wired: Using web-based corpora in critical discourse analysis. Discourse \& Society, 24 (6), 809-828.

Mayr, A. (2008) (ed.) Language and Power: An Introduction to Institutional Discourse London: Continuum International Publishing Group.

McGrath, J. E. (2004) Loving Big Brother: Performance, Privacy, and Surveillance Space. Routledge: London.

Mercea, D. (2013) Probing the Implications of Facebook use for the organizational form of social movement organizations. Information, Communication and Society, 16 (8), 1306-1327.

McNeill, D. (2005) Gesture and Thought. Chicago: University of Chicago Press.

Papacharissi, Z. (2002). The Virtual Sphere: The Internet as the Public Sphere, New Media \& Society, 4(1), 5-23.

Papacharissi, Z. (2010). A Private Sphere: Democracy in a Digital Age. Cambridge: Polity Press.

Phillips, L. and Jorgensen, M. (2002) Discourse Analysis as Theory and Method. London: Sage.

Preiskel, D. and Green, D.A. (2011) The "Twitter Joke Trial" - The High-Profile UK Legal Case On Social Media And Criminal Liability. Who's Who Legal.

http://whoswholegal.com/news/features/article/29377/the-twitter-joke-trial-high-profile-uklegal-case-social-media-criminal-liability/ [Accessed 30 July 2013].

Ransom, J.S. (1997) Foucault's Discipline: The Politics of Subjectivity. London: Duke University Press.

Richardson, J. (2007) Analysing Newspapers: An approach from critical discourse analysis Basingstoke: Palgrave Macmillan. 
Rheingold, H. (1992) 'A Slice of Life in My Virtual Community' in Ludlow, P. (ed.) (1999) High Noon on the Electronic Frontier: Conceptual Issues in Cyberspace. MIT Press: Massachusetts.

Strudwick, P. (2013) 'Sally Bercow's Lord McAlpine libel: Twitter is over. O.V.E.R.' The Guardian. 24 May 2013. http://www.guardian.co.uk/commentisfree/2013/may/24/sallybercow-lord-mcalpine-libel-twitter [Accessed 30 July 2013].

Taylor, M. (2013) Twitter's response to rape threats 'inadequate', says Yvette Cooper. The Guardian. 29 July 2013. http://www.guardian.co.uk/politics/2013/jul/28/yvette-coopertwitter-response-rape-threats [Accessed 30 July 2013].

Thurlow, C. and Mroczek, K. (2010) Digital Discourse: Language in the New Media. New York: Oxford University Press.

Unger, J. (2012) 'New tools for critical discourse studies in new media contexts'. Paper presented at Critical Approaches to Discourse Analysis Across Disciplines, University of Minho, Braga, Portugal, 4-6 July. http://johnnyunger.wordpress.com/2012/07/05/criticalapproaches-to-discourse-analysis-across-disciplines-2012/ [Accessed 25 November 2013]

van Dijk, T. (1998) 'Opinions and Ideologies in the Press' in Bell, A. and Garrett, P. (eds) Approaches to Media Discourse West Sussex: Wiley-Blackwell.

van Dijk, T. (2001) Discourse, Ideology and Context, Folia Linguistica, Volume 35 (1-2), 11-40.

Wakefield, J. (2010) World Wakes up to Digital Divide. BBC News. 19 March 2010. http://news.bbc.co.uk/1/hi/technology/8568681.stm [Accessed 30 July 2013].

Wodak, R. et al. (1999) The Discursive Construction of National Identity. Edinburgh: Edinburgh University Press.

Wodak, R. (2001) 'What CDA is about - a summary of its history, important concepts and its developments' in Wodak, R. and Meyer, M. (eds.) Methods of Critical Discourse Analysis London: Sage.

Wodak, R. (2008) 'Introduction: Discourse Studies - Important Concepts and Terms' in Wodak, R. and Krzyzanowski, M (eds.) Qualitative Discourse Analysis in the Social Sciences Basingstoke: Palgrave Macmillan.

Wodak, R. and Wright, S. (2006) 'The European Union in Cyberspace. Multilingual Democratic Participation in a virtual public sphere?' Journal of Language and Politics, vol 5, no. 2, pp. 251-275. 